\title{
Locations, Programs, and Content of Graduate Education in Business Communication
}

\author{
Stephen A. Carradini ${ }^{1}$, Matthew J. Baker ${ }^{2}$, Matthew R. Sharp ${ }^{3}$, Elise Davidson ${ }^{2}$ \\ 'Arizona State University, Tempe, AZ, USA \\ ${ }^{2}$ Brigham Young University, Provo, UT, USA \\ ${ }^{3}$ Embry-Riddle Aeronautical University, Daytona Beach, FL, USA
}

Objectives: This study explored locations, programs, and content of graduate education in business communication to provide guidance for prospective graduate students interested in becoming business communication faculty.

Methods: The researchers conducted a survey of business communication scholars, drawing on the backgrounds and knowledge of those who currently teach and research business communication.

Results: Findings indicate that 93 universities offer programs supporting graduate business communication education. This number dwarfs the 12 previously documented programs. These 93 programs are rarely called "business communication." More respondents received training in business communication practice in master's programs than in doctoral programs, while more respondents received training in pedagogy and methods during doctoral work than master's work. The majority of respondents reported being employed by business schools despite receiving their degrees from colleges of arts and sciences, communication, or education. Conclusions: Graduate students can use the list of 93 universities to investigate possible graduate programs in business communication. Students will likely need to pursue graduate education outside of business schools, because the majority of respondents did not receive their graduate degrees from business schools. Earning a doctorate will likely give students methodological knowledge that a master's program may not provide. To bolster their experience with the context of business communication, graduate students may need to gain some experience in the practice of business communication via internship or elective business school coursework.

Key Words: Graduate Education, Course Content, Programs, Pedagogy, Faculty

\section{Introduction}

Scholars in business communication hail from a variety of disciplinary and institutional backgrounds (Laster \& Russ, 2010, p.

Received: Oct 5, 2019 Revised: Nov 30, 2019 Accepted: Dec 16, 2019 Corresponding author: Stephen A. Carradini 7271 E. Sonoran Arroyo Mall, 251F, Mesa, AZ 85212-2780, USA

Tel: +1-480-727-3687, E-mail: Stephen.Carradini@asu.edu

This is an Open Access article distributed under the terms of the Creative Commons Attribution Non-Commercial License (http://creativecommons.org/licenses/ by-nc/4.0/) which permits unrestricted non-commercial use, distribution, and reproduction in any medium, provided the original work is properly cited.

Copyright ( 12020 Korean Association for Business Communication.
249). This diversity strengthens business communication scholarship through the infusion of new ideas and opportunities for collaboration (Forman \& Markus, 2005; Locker, 1994). However, this diversity poses a problem for graduate students who need a clear educational path to acquire the training necessary for faculty positions in business communication: students may wonder where prospective business communication faculty can or should seek training to be well-equipped for the role (Suchan \& Charles, 2006, p. 397).

Compounding this problem is the fact that few graduate programs in business communication are documented, and the names of documented programs do not clearly convey a focus on business communication. As shown in Table 1, the Associa- 
tion for Business Communication (ABC) lists only 12 graduate programs related to the discipline on its website; these programs have ten different names (ABC, 2019). Only four master's programs include the phrase business communication, and no doctoral programs include the phrase in their names. Master's programs, doctoral programs, postdoctoral positions, and certificates supporting business communication study exist in fields such as communication and English; these spaces may or may not include the phrase business communication in their names (Laster \& Russ, 2010; Rainey, 1999; Russ, 2009; The Regents of the University of California, 2019; Writing and Communication Program, 2019). Ultimately, a student is likely to enroll in a program not named business communication to prepare for a position in business communication. Thus, it is critical that graduate students in business communication know which programs support graduate education in business communication, despite the programs not suggesting that support in their names.

Furthermore, documentation of the institutional locations of those departments needs to be expanded and updated. The website of the Korean Association for Business Communication (KABC) currently provides no information about graduate education in business communication (KABC, 2019). At the time of the writing of this article, $A B C$ 's list of graduate programs contained programs that no longer exist (ABC, 2019). Prospective business communication graduate students who discover these organizations' websites may be disconcerted at the apparent lack of opportunity for studying business communication at the graduate level.

Research on geographic and departmental locations of grad- uate education in business communication is limited and outdated. Business communication scholarship as a whole has not recently explored which departments and universities confer graduate degrees, as the disciplines of communication and rhetoric \& composition have done for their fields (Barnett, Danowski, Feeley, \& Stalker, 2010; Brown, Enos, Reamer, \& Thompson, 2008). The most comprehensive work on business communication graduate education came via the members of the 1971 Graduate Studies Committee of the American Business Communication Association-a previous name for the organization that is now the Association for Business Communication (Hatch, 1973). This survey, which sought to determine what programs offer business communication at the graduate level, resulted in 85 schools of business that taught " 178 graduate-level courses in Business Communication, taught by a total of 179 faculty members" (p. 32). The researchers found that business communication scholars who taught in those 85 schools of business were housed not only in business, but in speech communication, education, English, journalism, and psychology departments. The committee also found "majors, minors, or substantial concentrations" that "range from areas of concentration involving as few as three courses in a Masters [sic] program to Ph.D. majors" in 14 business schools. (p. 35). Notably, none of these programs were located out of the United States. This lack of programs outside of the U.S. suggests a clear need beyond chronological updates to revisit this topic, given an emphasis by $\mathrm{ABC}$ to expand its membership beyond North America (Dubinsky, 2019). Since Hatch's (1973) study, research on where graduate business communication degrees are conferred is nonexistent. A need exists for scholars to renew scholarly conversations about the

Table 1. ABC's list of universities and programs for graduate study of business communication

\begin{tabular}{llc}
\hline University & \multicolumn{1}{c}{ Degree } & Survey response \\
\hline American University & Master's - Strategic Communication - online & No \\
Arizona State University & Master's - Technical Communication - online & Yes \\
East Carolina University & PhD - Rhetoric, Writing, and Professional Communication & Yes \\
lowa State University & PhD, master's - Rhetoric and Professional Communication & Yes \\
La Salle University & Master's, certificate program - Business and Professional Communication & Yes \\
Queens University of Charlotte & Master's - Communication - online & No \\
Rider University & Master's - Business Communication & No \\
Spalding University & Master's, certificate program - Business Communication & No \\
Texas Tech University & PhD, master's - Technical Communication and Rhetoric & Yes \\
University of Minnesota Department & PhD, master's - Rhetoric and Scientific and Technical Communication & No \\
of Writing Studies & & Yes \\
University of St. Thomas & Master's - Business Communication & \\
University of Wisconsin-Milwaukee & PhD, master's - Professional and Technical Writing & \\
\hline
\end{tabular}

Note. ABC, Association for Business Communication. 
locations of graduate education in business communication.

Another concern about business communication graduate education concerns related fields. Business communication is often discussed in conjunction with organizational communication, corporate communication, commercial communication, managerial communication, and professional communication; Shelby (1993) argues that business communication overlaps with but is not completely subsumed by any of organizational, management, and corporate communication (p. 261). Given that business communication shares some concerns with these fields but is not a subset of these, it is unclear whether business communication can be studied in any or all of the programs that support these various fields. We assume that some may be friendly to business communication graduate work due to overlapping concepts, while others may be more focused on their core (named) concern. Only experts with knowledge of individual programs can note which programs are which; it is not clear that systematic searching of the web would consistently return the types of information for each program that would make it clear which ones include pedagogy on how to teach the written and oral production of communication instead of primarily how to teach organizational theory.

Because we know little about where business communication graduate education is conducted, we also know little about the current content of that graduate education. This lack stands in stark contrast with knowledge of undergraduate education, which is a common topic in business communication research (Chang, Park, \& Cho, 2018; Laster \& Russ, 2010; Russ, 2009). Only one proposal for doctoral education in business communication exists (Wunsch, 1978). It focuses on skills and genres of everyday speech and writing in business contexts, delivered in a skills course, a "concepts and methods" course, a research course, and an internship or work experience to fill out the doctoral program (p. 22). No known business communication doctoral programs currently follow this proposal. Lease (1985) took a different tack, detailing a course taught to business doctoral students about pedagogy (p. 67). Munter's (1983) survey of communication offerings in $17 \mathrm{MBA}$ programs found that courses offered advanced skills, oral and written components, peer response, instructor response, managerial focus, teaching on how to analyze, and skills education (pp. 9-10). Her study also found that business schools administered business communication graduate education in four ways: "required course, diagnostic test, integrated course, or elective course" (p. 7). These articles emphasize pedagogy, research methods, and practice as areas of graduate education. Continued study of the content of business communication education in graduate programs is needed to update current knowledge and to provide graduate students with insight into the type of work conducted in business communication graduate programs.

Graduate education is a critical step towards the professoriate; not knowing where graduate education is currently happening or what type of education is currently provided limits knowledge of what new professors in business communication can be expected to know. Thus, business communication scholarship needs to begin exploring two types of information to better develop future faculty: (1) which disciplines and institutions house graduate education in business communication and (2) what types of training teachers and scholars receive while studying business communication. Knowing this information could expand the documentation of currently known graduate programs in business communication and provide information for graduate students interested in preparing themselves for faculty positions in business communication. Thus, we explored these research questions in this study:

RQ1: In what departments did current business communication teachers and scholars receive their graduate degrees/training?

RQ2: What was the content of that business communication training?

RQ3: Where are graduate programs in business communication currently located, both geographically and departmentally?

To explore these questions, we conducted a survey of business communication instructors. In this study, we present an overview of our survey, our exploratory results, a discussion of these results, and concluding implications for graduate students interested in pursuing graduate training in business communication for the purpose of becoming business communication faculty.

\section{Methods}

We created a survey to assess the location of business communication scholars' graduate education, the content of that graduate education, and the knowledge that respondents have of current graduate education locations. Ultimately, the project relied on a short online survey design (Couper, Traugott, \& Lamias, 2001) administered via e-mail to Association for Business Communication members. Querying faculty in relation to understanding the locations and content of graduate education is common in related fields such as communication and rhetoric \& composition (Applegate, Darling, Sprague, Nyquist, \& Andersen, 1997, p. 115, 119; Brown et al., 2008; Covino, Johnson, \& Feehan, 1980). 


\section{Survey Design}

The IRB-approved survey instrument can be found in Appendix 1 . To explore locations where business communication might be studied at the graduate level, business communication instructors were asked to provide their current position, department, and university; to indicate whether their current university provides opportunities for students to study business communication at the graduate level; and to name other institutions where the instructor knew business communication could be studied. To explore the content of graduate education in business communication, instructors were asked to provide their educational degrees (undergraduate, master, doctoral, post-doctoral) and the content of their education (practice, theory, pedagogy, research methods). We conducted a pilot study with nine instructors to assess whether respondents understood the survey questions and whether the questions resulted in valid data. After making minor adjustments, we proceeded to respondent selection.

\section{Inclusion and Exclusion Criteria}

To explore possible locations and content of graduate education, the study focused on the educational backgrounds and knowledge of those who teach business communication. The survey targeted individuals who self-selected to be active members of $A B C$ because these individuals teach and/or research business communication. $\mathrm{ABC}$ is an international organization that supports business communication teaching and research; the current number of active members of $\mathrm{ABC}$ is approximately 850. ABC conducts most of its work in English, although it has conducted Spanish-language panels at its international conference; this focus on English as its primary language could put the focus of the results on primarily universities that conduct their work in English. Despite this limitation, we felt that surveying individuals with active memberships in $\mathrm{ABC}$ provided a level of assurance that survey results would reflect the graduate education of current instructors and researchers in business communication.

\section{Recruitment Methods}

The researchers secured permission from the $A B C$ Executive Committee to survey the organization's full membership. The authors distributed the survey via the $\mathrm{ABC}$ listserv. Data collection lasted for 18 days, from February 1 to February 18, 2018. From a survey population of 850 , the survey received a $21 \%$ open rate (174) and a $13 \%$ completion rate (114). The lack of recent research on this topic resulted in an exploratory survey that required us to rely on open-ended questions instead of multiple-choice questions. This necessarily exploratory meth- odology may have contributed to the difference between open rate and completion rate. This response rate is acceptable for survey research, as Moshiri and Cardon (2014) received a similar response rate (14\%, or 169 respondents) in their survey of 1,100 business communication instructors.

\section{Results}

In this section, we state demographic information and then report findings related to the study's three research questions: (1) where current business communication instructors received their graduate degrees or training, (2) what the curricular content of those degrees or training consisted of, and (3) the current locations of graduate programs in business communication.

\section{Demographic Findings}

Respondents reported their academic position(s), primary country of residence, and academic college(s). Tenure-line faculty composed the largest group: 66 (56.9\%) reported titles of professor, associate professor, or assistant professor. Non-tenure-track faculty constituted the next largest group: 36 (31\%) reported titles including the word lecturer, instructor, clinical, or of practice. Other positions appeared infrequently: 13 (11.2\%) reported titles including graduate student, consultant, faculty, or others. The respondents reported working primarily in the United States: Ninety-eight (86\%) respondents reported being located primarily in the United States, 12 (11\%) reported being from outside the United States, and six respondents (5\%) chose not to report their location. Respondents belonged to two main academic colleges. A majority of respondents $(67.5 \%, 77$ respondents) reported working in a college of business, and 31 respondents (27\%) reported being housed in a college of arts and sciences. Respondents were located in a variety of institutions (Table 2).

\section{Graduate Degrees/Training of Respondents}

Respondents reported receiving their graduate degrees and training from various sources. They reported receiving master's degrees (Figure 1) in

- The arts and sciences (35\%), which primarily included degrees in literature, English, rhetoric, professional communication, or technical communication;

- Communication (20\%), which primarily included degrees in communication or communication studies, speech communication, intercultural communication, interpersonal communication, and organizational communication;

- Education (20\%), which primarily included degrees in higher education, educational leadership, educational psy- 
Table 2. Universities where respondents reported working

\begin{tabular}{|c|c|c|}
\hline University (A-M) & University (M-U) & University (U-Z) \\
\hline Arizona State University & Muskegon Community College & University of Louisiana \\
\hline Baylor University & Naval Postgraduate School & University of Louisville \\
\hline Boise State University & North Carolina A\&T State University & University Of Maryland \\
\hline Brigham Young University & North Carolina Central University & University of Michigan \\
\hline California State University, Northridge & Northwestern State University & University of Minnesota, Twin Cities \\
\hline Computershare (most recent employment) & Oakland University & University of Mount Olive \\
\hline DePaul University & Oklahoma State University & University of Nebraska Omaha \\
\hline Drake University & Pfeiffer University & University of North Carolina at Chapel Hill \\
\hline East Carolina University & Ryerson University & University of North Dakota \\
\hline Eastern Illinois University & Saint Mary's University & University of North Georgia \\
\hline Eastern Kentucky University & Sam Houston State University & University of North Texas \\
\hline Eastern Michigan University & Southern Arkansas University & University of Northern lowa \\
\hline Flinders University & Southwest Minnesota State University & University of Nottingham Ningbo China \\
\hline Florida Atlantic University & St. Cloud State University & University of South Florida \\
\hline Fort Hays State University & São Paulo State Technological College & University of Southern California \\
\hline Girne American University & Stephen F. Austin State University & University of Tennessee at Martin \\
\hline Indian Institute of Management Bangalore & Tarrant County College & University of West Florida \\
\hline Indiana University & Temple University & University of Wisconsin-Eau Claire \\
\hline lowa State University & Texas A\&M International University & University of Wisconsin-Milwaukee \\
\hline Jacksonville University & The Citadel & Utah Valley University \\
\hline Kent State University & The University of Texas at Dallas & Virginia Tech \\
\hline Mainz University of Applied Sciences & Tulane University & West Chester University \\
\hline Middle Tennessee State University & University of California, Santa Barbara & Western Oregon University \\
\hline Morgan State University & University of Cape Town & Widener University \\
\hline Morningside College & University of Cincinnati & Xavier University Bhubaneswar \\
\hline Mt. Hood Community College & University of Kansas & Zayed University, United Arab Emirates \\
\hline
\end{tabular}

chology, instructional systems technology, and business;

- Business (17\%), which primarily included degrees in business administration or management.

Doctoral training (Figure 2) originated from similar areas, including the arts and sciences (34\%), communication (21\%), education (16\%), and business (7\%). Only seven respondents reported completing postdoctoral work, with such work taking place in the arts and sciences (3 respondents, $2 \%$ ), in education $(2,2 \%)$, and in business $(2,2 \%)$. Despite respondents' connection to business communication, the majority lacked graduate training from business schools. Outside of formal education, 13 respondents reported gaining additional training or certification in a variety of areas: English (2); Interactive Multimedia (2); Business Management (Marketing), IT Network Infrastructure; Composition \& Rhetoric; Conflict Resolution; Educational Mid-Management Certification; Human Resource Management; Linguistics; Music; Pedagogy and Teaching; and Technical Writing.

\section{Content of Respondents' Business Communication Training}

Respondents reported most frequently receiving business communication training related to practice in bachelor's programs, related to theory in master's programs, and related to research methods in doctoral programs. Doctoral programs also appear to provide relatively more training in pedagogy than master's programs (Figure 3). Only 21 respondents (18\%) did not report doctoral work, leaving 95 respondents who reported holding a doctorate. Of these 95, only 53 (56\%) received instruction in practice in their doctoral program. Those who completed postdoctoral work reported receiving training in equal frequency in practice, theory, and pedagogy. Also, other training or education that respondents pursued outside of their primary master's and doctoral programs appears to prioritize practice. Notably, 24 of 34 (71\%) of those reporting additional training in practice hold doctoral degrees. Overall, respondents reported least frequently receiving training in pedagogy and research methods. 


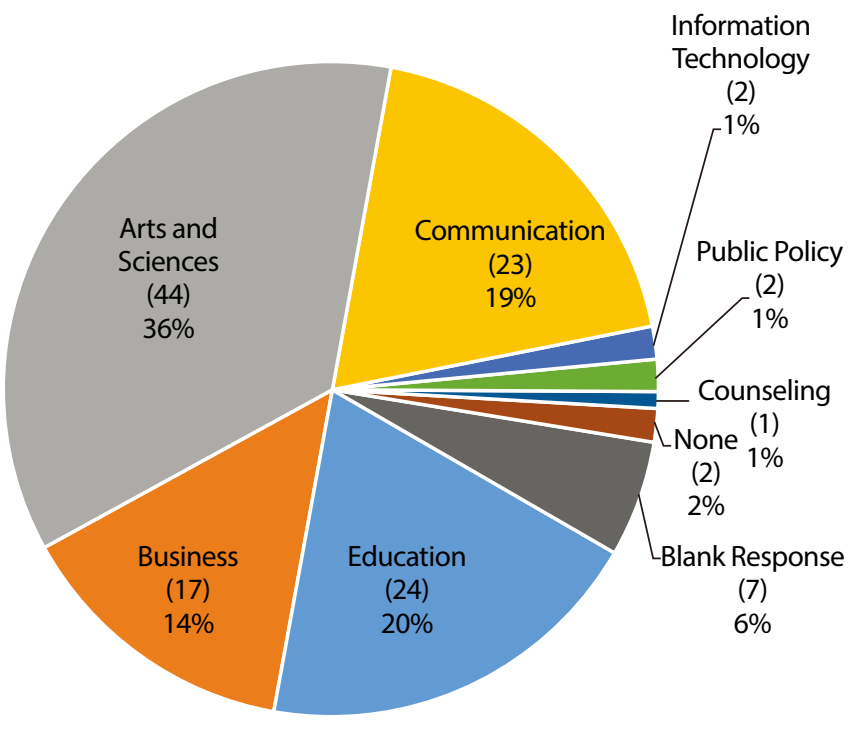

Figure 1. Master's degree fields reported by respondents. The total adds up to 122 instead of 116, because 6 responses indicated the respondent received two master's degrees. While Arts and Sciences contains the largest share of the degrees, the areas where respondents did their master's work are diverse.

\section{Location of Graduate Programs in Business Communication}

While $51 \%$ of respondents reported that students at their institution could not study business communication at the graduate level, more than one-third of participants (34\%) reported that students at their institution could (Figure 4). Respondents also reported a number of other universities or programs where graduate students can study business communication. Table 3 reflects universities and programs where business communication can be studied. Due to the potential for respondents to misremember programs, the inevitability of programs changing over time,

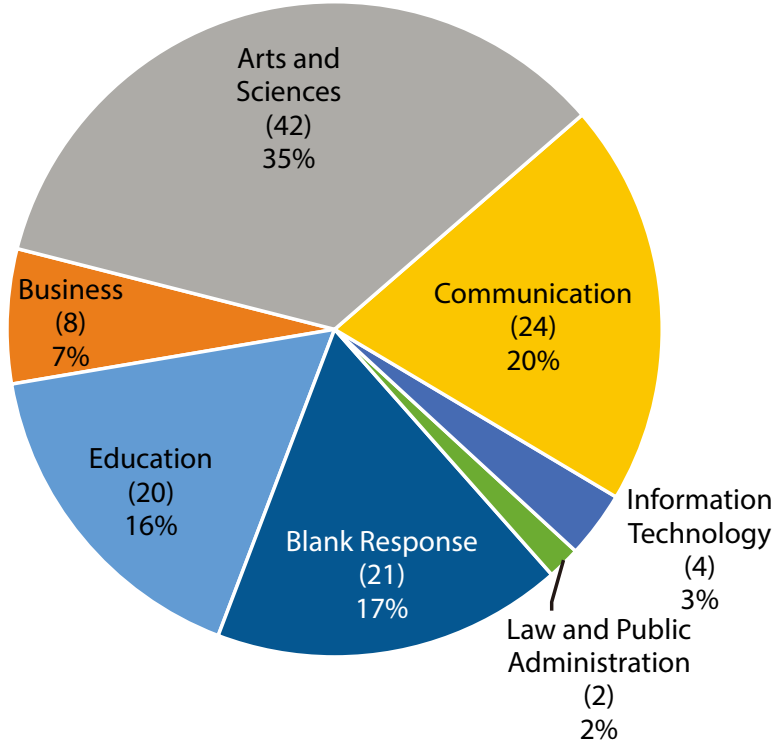

Figure 2. Doctoral degree fields reported by respondents. The total is 121 instead of 116, because 5 respondents indicated they received 2 PhDs. This category was left blank by 21 respondents; we suggest that this means these respondents may not hold a doctorate or declined to give information about their doctoral work. The categories of Arts and Sciences, Communication, and Education hold steady in their percentage share in relation to master's degrees, while business declines and blank response increases.

and a brief time gap between survey close and publication, the researchers confirmed that reported programs still existed and checked for any changed program names. Authors removed programs that no longer exist and updated the entries of programs with changed names. Respondents reported 39 programs in 19 U.S. states and five non-U.S. countries.

Table 4 lists universities that respondents provided without specifying program names, making it unclear where business

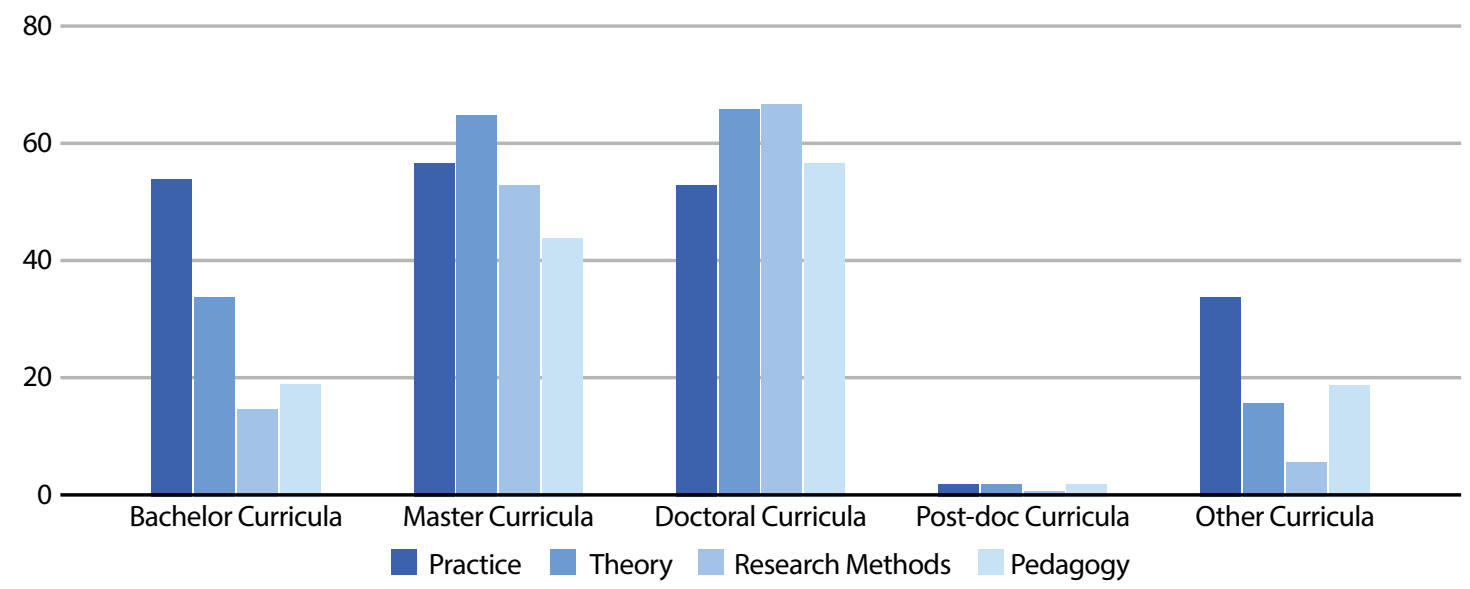

Figure 3. Contents of respondents' training in their various educational locations. Practice fluctuates somewhat between undergraduate, master's and doctoral education, while the numbers of respondents reporting research methods and pedagogy education increase from undergraduate to master's to doctoral work. 


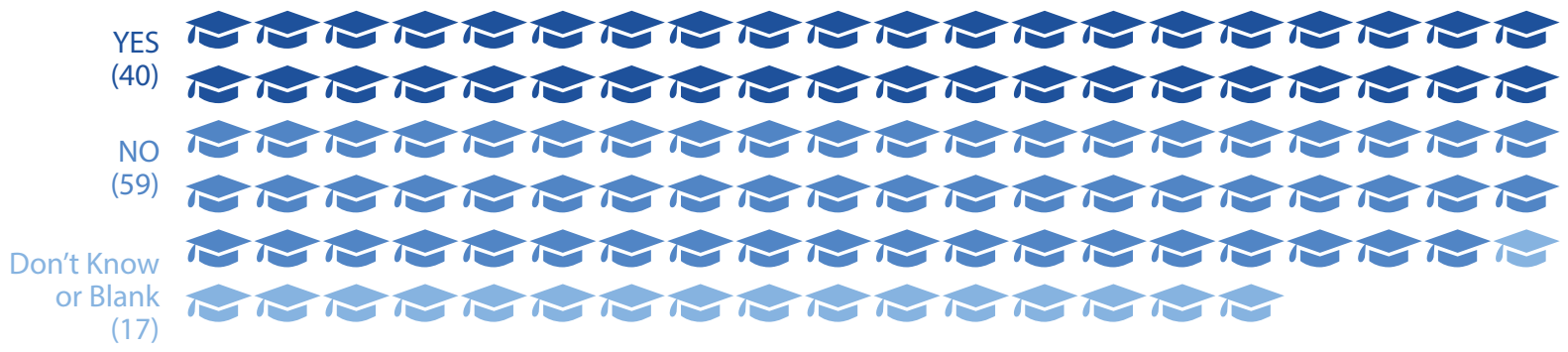

Figure 4. Availability of graduate program at respondents' universities. The majority of respondents reported no or don't know. The number of respondents reporting yes is higher than the overall number of locations reported because multiple representatives from the same institution could respond.

Table 3. Reported programs for graduate study of business communication

\begin{tabular}{|c|c|}
\hline University & Program \\
\hline Arizona State University & MS, Technical Communication \\
\hline Baylor University & MA, Communication \\
\hline California State University, Northridge & MA, English: Rhetoric and Composition \\
\hline Columbia University & $\begin{array}{l}\text { MA, Strategic Communication } \\
\text { Executive Master's, Strategic Communication } \\
\text { MS, Strategic Communication }\end{array}$ \\
\hline DePaul University & MA, Communication and Media, Organizational Communication concentration \\
\hline East Carolina University & $\begin{array}{l}\text { PhD, Rhetoric, Writing, \& Professional Communication } \\
\text { MA, English, Rhetoric and Composition } \\
\text { MA, English, English/Technical \& Professional Communication } \\
\text { Graduate Certificate in Professional Communication }\end{array}$ \\
\hline Fort Hays State University & MBA, Corporate Communication Concentration \\
\hline Girne American University, Cyprus & $\begin{array}{l}\text { MA in Business Management, } \\
\text { PhD in Business Management, } \\
\text { PhD in Communication \& Media Management }\end{array}$ \\
\hline Harvard & Business Communication Certificate \\
\hline lowa State & $\begin{array}{l}\text { MA in Rhetoric and Professional Communication } \\
\text { PhD in Rhetoric and Professional Communication }\end{array}$ \\
\hline Kent State University & PhD, Rhetoric and Composition: Workplace Literacy \\
\hline Mainz University of Applied Sciences, Germany & MA, International Business \\
\hline Massey University, New Zealand & Master of Business Studies (Communication) \\
\hline New Mexico State University & $\begin{array}{l}\text { MA, Rhetoric \& Professional Communication } \\
\text { PhD, Rhetoric and Professional Communication }\end{array}$ \\
\hline Oklahoma State University & $\begin{array}{l}\text { MA, English with an Option in Professional Writing } \\
\text { MA, English, Rhetoric and Writing Studies } \\
\text { PhD, English, Professional Writing }\end{array}$ \\
\hline Purdue University & $\begin{array}{l}\text { MA, Rhetoric and Composition } \\
\text { PhD, Organizational Communication }\end{array}$ \\
\hline Rhodes University, Grahamstown, South Africa & $\begin{array}{l}\text { MA, Journalism and Media Studies, } \\
\text { PhD, Journalism and Media Studies }\end{array}$ \\
\hline Sam Houston State University & MA, Communication Studies, Organizational Communication \\
\hline St. Cloud State University & MA, Rhetoric and Writing \\
\hline Stellenbosch University, South Africa & $\begin{array}{l}\text { MA, Journalism } \\
\text { PhD, Journalism }\end{array}$ \\
\hline Texas A\&M International University & MA, Communication \\
\hline Texas A\&M University & $\mathrm{PhD}$, Organizational Communication \\
\hline Texas Tech University & PhD, Technical Communication and Rhetoric \\
\hline
\end{tabular}


Table 3. continued

\begin{tabular}{|c|c|}
\hline University & Program \\
\hline Towson University & MS, Professional Writing \\
\hline University of California, Santa Barbara & Technology Management Program (multiple degrees) \\
\hline University of Cape Town, South Africa & Postgraduate Diploma, Management specializing in Business Communication \\
\hline University of Cincinnati & $\begin{array}{l}\text { Professional Writing Certificate } \\
\text { MA, Professional Writing } \\
\text { MA, Communication }\end{array}$ \\
\hline University of Kansas & $\begin{array}{l}\text { MA, Communication Studies } \\
\text { PhD, Communication Studies }\end{array}$ \\
\hline University of Minnesota, Twin Cities & $\begin{array}{l}\text { MA, Rhetoric and Scientific \& Technical Communication } \\
\text { PhD, Rhetoric and Scientific \& Technical Communication }\end{array}$ \\
\hline University of Nottingham Ningbo China & MSc, Intercultural and Professional Communication \\
\hline University of Pretoria & PhD, Communication Management \\
\hline University of Texas at Austin & $\begin{array}{l}\text { MA, Organizational Communication and Technology } \\
\text { PhD, Organizational Communication and Technology }\end{array}$ \\
\hline University of West Florida & MA, Literature or Creative Writing \\
\hline University of Wisconsin-Eau Claire & Business Communication certificate \\
\hline Utah State University & PhD, Technical Communication and Rhetoric, M.A. Technical Communication \\
\hline University of Wisconsin-Milwaukee & MA, Rhetoric and Professional Writing \\
\hline Virginia Tech & PhD, Rhetoric and Writing \\
\hline Waikato University, New Zealand & Master of Management Studies, Leadership Communication as a Main Subject \\
\hline Youngstown State University & MA, English, Professional and Technical Writing Track \\
\hline
\end{tabular}

Table 4. Reported universities where specific programs were not mentioned

\begin{tabular}{|c|c|}
\hline University (A-Q) & University (R-Z) \\
\hline Aalto University, Finland & Radboud University, The Netherlands \\
\hline Auburn University & Radford University \\
\hline Brigham Young University & Rensselaer Polytechnic Institute \\
\hline Carleton College & Rowan University \\
\hline Catholic University of Sao Paulo, Brazil & Ryerson University, Canada \\
\hline Central Michigan University & St. Thomas University \\
\hline Centro Universitário Salesiano de São Paulo, Brazil & Temple University \\
\hline Clemson University & University of Oregon \\
\hline Cornell University & University of Alabama \\
\hline Drexel University & University of British Columbia, Canada \\
\hline Eastern Michigan University & University of Illinois \\
\hline Governors State University & University of Louisville \\
\hline La Salle University & University of North Carolina at Chapel Hill \\
\hline Macquarie University, Australia & University of Northern lowa \\
\hline Michigan State University & University of Sao Paulo, Brazil \\
\hline New York University & University of South Dakota \\
\hline North Carolina State University & University of Toronto, Canada \\
\hline Northcentral University & University of Washington \\
\hline Northwestern University & University of Waterloo, Canada \\
\hline Nottingham University, UK & Villanova University \\
\hline Old Dominion University & Warwick University, UK \\
\hline Oregon State University & West Chester University \\
\hline Portland State University & York University, UK \\
\hline
\end{tabular}


communication may be studied programmatically within the universities. The universities are located in 17 U.S. states and six non-U.S. countries; one university is online-only.

Some respondents indicated that business communication could be studied or researched in courses within an MBA program. While such courses provide valuable training, they could be considered service courses. These service courses may differ from disciplinary program courses that prepare graduate students to become business communication scholars and teachers. These universities were Baruch College, Naval Postgraduate School, Pfeiffer University, Sam Houston State University, São Paulo State Technological College, Stephen F. Austin State University, University of North Texas, and University of Southern California. These responses included four U.S. states and one non-U.S. country.

Considering all three categories of response together, respondents identified 93 universities as locations of potential graduate study in business communication. These include 28 U.S. states, 11 non-U.S. countries, and one online university. Respondents identified programs in Texas (9 universities), New York (5 universities), Pennsylvania (5), California (4), Illinois (4), North Carolina (4), Ohio (3), Michigan (3), Minnesota (3), Oregon (3), Virginia (3), Alabama (2), Florida (2), Iowa (2), Kansas (2), Wisconsin (2), Utah (2), Arizona, Indiana, Kentucky, Maryland, Massachusetts, New Mexico, New Jersey, South Carolina, South Dakota, Oklahoma, and Washington. Respondents also identified universities in Brazil (4), Canada (4), South Africa (4), UK (3), New Zealand (2), Australia, China, Cyprus, Finland, Germany, and The Netherlands.

\section{Discussion}

Findings indicate that most respondents received graduate training outside of business schools. The majority of respondents pursued master's work in the arts and sciences or in communication-related disciplines. Respondents reported conducting the majority of doctoral work in these disciplines as well. Less frequently, respondents pursued graduate work in education and business. Post-doctoral work of any type is rare for business communication scholars. The lack of a common discipline for business communication graduate education may contribute to a lack of easily recognizable programs: no matter where the program is housed, programs where business communication can be studied are rarely titled Business Communication. These findings provide some support for Suchan and Charles' (2006) opinion that business communication would benefit from its own Ph.D. programs, but as they observe, "more than likely, though, we will have to do what we have done in the past: attract talented $\mathrm{PhDs}$ from other disciplines-English, speech communication, rhetoric, organizational communication" (Suchan \& Charles, 2006, p. 397). The findings of the present study suggest that such attraction is occurring.

Graduate students plotting an educational path toward teaching business communication might thus explore master's and doctoral degrees in communication or communication studies, English, intercultural communication, interpersonal communication, literature, professional communication, technical communication, organizational communication, rhetoric, and speech communication. A degree in literature may not seem as related to business communication as technical communication, communication, or rhetoric, yet some survey respondents reported literature degrees as their educational background. Based on the current positions of the respondents, these degrees would seem to prepare and qualify graduate students for teaching business communication. While scholars might hope for a clear pathway from degrees named business communication to a position teaching business communication, this pathway largely still does not exist, and "doctoral programs in business communication per se remain elusive" (Graham \& Thralls, 1998, p. 8).

The lack of business communication degrees from business schools appears not to have stopped faculty from gaining appointment in business schools. Despite only $20 \%$ of respondents receiving graduate training from business schools, $66 \%$ of them work in business schools. This large number of faculty housed in business schools corroborates findings of Russ (2009), who reported that $59.6 \%$ of respondents noted that the business school houses their introductory business courses. While this finding is an imperfect measure-faculty can teach a course sponsored by the business school but be jointly appointed or fully appointed in other schools, as Hatch (1973) notes-it shows that the business school continues to dominate the locations of business communication teaching, despite not producing the majority of graduate degrees. This seeming disconnect between location of education and location of work could be encouraging for graduate students interested in teaching business communication in business schools but whose current graduate work resides outside of business.

However, the disconnect prompts questions about where responding faculty received training in the theory of business communication that would presumably have occurred during graduate work within a business school. This concern is particularly true of degrees whose focus traditionally ranges far afield from business concerns, such as literature or education (Hatch, 1973, p. 32). Additional findings suggest that respondents received their training in business communication theory at the 
master's level, where the majority of respondents received their training primarily in communication-related degrees. Communication-related theory thus seems to form the theory base for a large number of respondents, indicating that the business aspect of business communication is learned through other means.

The findings suggest that many respondents came to their graduate education with practice in business communication gained through a bachelor's degree, or they sought additional training in practice outside their graduate education. Wunsch (1978) recommends that doctoral students in business communication complete an "internship or work experience requirement" because "by working in an organizational setting for a period of time, the student can apply much of the theory previously learned in the classroom" (p. 22). The findings of this study would support business communication doctoral programs including an internship or work opportunity to help graduate students gain more practice in business, despite infrequent inclusions of internships in other fields' doctoral work. Another way to address this gap of business practice could be for graduate students to take doctoral elective courses in marketing, management, strategy, or other business fields.

The second research question investigated the content of graduate education in business communication, with the survey asking respondents to report the content they studied in their own undergraduate and graduate education. The findings indicate that an almost equal number of respondents reported receiving training in practice in undergraduate, master's, and doctoral programs. Many more respondents reported receiving training in theory, pedagogy, and research methods in graduate education than in undergraduate education. This finding shows that graduate education in business communication builds on and extends a base of undergraduate education, indicating the existence of healthy graduate programs that do not replicate or replace undergraduate education.

Of the findings comparing master's and doctoral work, more respondents noted receiving training in practice in the master's degree than the doctoral degree. Roughly the same number of people reported receiving training in theory in both master's and doctoral programs, while respondents reported training related to pedagogy and research methods more often in doctoral programs. This finding confirms that doctoral education often offers types of education beyond the scope of master's programs, making the pursuit of doctoral degrees particularly valuable and confirming the need for teaching pedagogical information to doctoral students (Lease, 1985).

Finally, the third research question investigated the locations of current graduate programs in business communication, and findings indicate that about a third of respondents work at institutions that offer programs where students can study or research business communication. Respondents provided 93 schools where graduate students could study business communication, including schools in 12 countries. This number expands on the previous list of graduate programs collected by ABC (2019). That list included 12 schools in 10 states and no locations outside the United States (Table 1). The study's findings also expand the dated findings of Hatch (1973) who found 14 programs where business communication could be a focus of graduate education, all within North America. While additional programs certainly exist, this survey data represents the largest number of graduate business communication locations yet compiled.

This study is not without its limitations. First, this particular survey included only ABC members. Future research might follow Moshiri and Cardon's (2014) lead to seek a pool of business communication scholars larger than $\mathrm{ABC}$ alone by including other academic organizations such as the Korean Association for Business Communication, Japan Business Communication Association, and the International Association of Business Communicators. Second, this survey relied on respondents' knowledge of other programs where business communication can be studied. Some universities were reported without program names where business communication can be studied; future research can shed light on which programs in these universities house business communication graduate education. Due to this methodological limitation, this article thus presents a starting point for restarting research on this issue, instead of a comprehensively researched list of places where graduate study in business communication can be pursued. The researchers recognize that other schools offering business communication graduate work need to be included on the list generated by this research, especially schools located outside of the United States. Future research using a different method, such as manually collecting the degree locations of faculty in business communication from faculty websites and dissertations (Barnett et al., 2010), could produce additional schools. The authors welcome email correspondence from readers letting us know of more places where business communication can be studied at the graduate level for use in future research.

\section{Conclusion}

This study explored the locations and content of graduate programs in business education by leveraging the knowledge of current scholars and teachers of business communication. The conclusions provide a number of implications for prospective faculty who desire to pursue graduate education in business 
communication:

- Graduate students will likely need to seek graduate education in business communication outside of business schools. The majority of respondents pursued master's and doctoral work in the arts and sciences or in communication-related disciplines, and no doctoral programs were reported with the title business communication.

- Respondents reported 93 institutions where students can pursue graduate education in business communication. Students can use this list as a starting point for researching schools where business communication can be studied at the graduate level.

- Graduate students interested in teaching business communication need not feel unqualified to apply for business communication positions if their graduate training occurred outside of a business school. The majority of respondents reported working within business schools, despite the majority of respondents receiving their education outside of business schools.

- Graduate students with an interest in business communication teaching but no professional background in business or business communication may need to seek work experience outside of their doctoral program. This type of experience, while suggested by Wunsch (1978) as a component of business communication graduate education, was the least common type of doctoral education received by students. Alternatively, students might take elective courses in marketing, management, strategy, or other business fields to better understand the context of business communication practice.

- Graduate students can benefit from pursuing graduate education at the doctoral level, where they will receive training different from that which they receive at the master's level. The majority of respondents reported receiving doctoral education that featured a stronger emphasis on research methods and pedagogy than master's level education.

These findings can help students find the educational pathway they need to prepare themselves for faculty positions in business communication.

\section{References}

Association for Business Communication. (2019). Graduate programs related to business communication. Retrieved from https://www.businesscommunication.org/page/resourcesgraduate-programs

Applegate, J. L., Darling, A., Sprague, J., Nyquist, J., \& Andersen, J. F.
(1997). An agenda for graduate education in communication: A report from the SCA 1996 Summer Conference. Communication Education, 46(2), 115-120.

Barnett, G. A., Danowski, J. A., Feeley, T. H., \& Stalker, J. (2010). Measuring quality in communication doctoral education using network analysis of faculty-hiring patterns. Journal of Communication, 60(2), 388-411.

Brown, S. C., Enos, T., Reamer, D., \& Thompson, J. (2008). Portrait of the profession: The 2007 survey of doctoral programs in rhetoric and composition. Rhetoric Review, 27(4), 331-340.

Chang, H., Park, P., \& Cho, S. (2018). An analysis of business communication courses in business schools and suggestions for curriculum development. Business Communication Research and Practice, 1(1), 33-40.

Couper, M. P., Traugott, M. W., \& Lamias, M. J. (2001). Web survey design and administration. Public Opinion Quarterly, 65(2), 230253.

Covino, W. A., Johnson, N., \& Feehan, M. (1980). Graduate education in rhetoric: Attitudes and implications. College English, 42(4), 390-398.

Dubinsky, J. M. (2019). Internationalizing the Association for Business Communication: A long journey, one step at a time, Business Communication Research and Practice, 2(1), 1-4.

Forman, J., \& Markus, M. L. (2005). Research on collaboration, business communication, and technology: Reflections on an interdisciplinary academic collaboration. International Journal of Business Communication, 42(1), 78-102.

Graham, M. B., \& Thralls, C. (1998). Connections and fissures: Discipline formation in business communication. International Journal of Business Communication, 35(1), 7-13.

Hatch, R. A. (1973). Business communication at the graduate level in American colleges of business. International Journal of Business Communication, 10(2), 29-37.

Korean Association for Business Communication. (2019). Korean Association for Business Communication. Retrieved from http:// www.kabc.re.kr

Laster, N. M., \& Russ, T. L. (2010). Looking across the divide: Analyzing cross-disciplinary approaches for teaching business communication. Business and Professional Communication Quarterly, 73(3), 248-264.

Lease, J. E. (1985). Teaching effectiveness: An intensive seminar for business Ph.D. students. International Journal of Business Com munication, 22(4), 67-73.

Locker, K. O. (1994). The challenge of interdisciplinary research. International Journal of Business Communication, 31(2), 137-151.

Moshiri, F., \& Cardon, P. (2014). The state of business communication classes: A national survey. Business and Professional Communication Quarterly, 77, 312-329. 
Munter, M. (1983). Trends in management communication at graduate schools. International Journal of Business Communication, 20(1), 5-11.

Rainey, K. T. (1999). Doctoral research in technical, scientific, and business communication, 1989-1998. Technical Communication, 46(4), 501-531.

Russ, T. L. (2009). The status of the business communication course at U.S. colleges and universities. Business Communication Quarterly, 72(4), 395-413.

Shelby, A. N. (1993). Organizational, business, management, and corporate communication: An analysis of boundaries and relationships. International Journal of Business Communication, 30(3), 241-267.
Suchan, J., \& Charles, M. (2006). Business communication research: Past, present, and future. International Journal of Business Communication, 43(4), 389-397.

The Regents of the University of California. (2019). Certificate business communications. Retrieved from https://www.uclaextension.edu/ business-management/leadership-management/certificate/business-communications

Writing and Communication Program. (2019). Brittain fellowship. Retrieved from https://wcprogram.lmc.gatech.edu/brittainfellowship

Wunsch, A. P. (1978). A supplementary business communications field for doctoral level students. Business and Professional Communication Quarterly, 41(3), 21-23. 


\section{Appendix}

\section{Appendix 1. Survey Instrument}

\section{Employment}

Current or Most Recent Position:

Current or Most Recent Department and/or College:

Current or Most Recent University / Organization:

\section{Education}

Please provide the degree name, granting institution, and year of graduation for all categories that apply. Please note any specializations, cognates, or certificates.

Bachelor's degree in

Master's degree in

Doctoral degree in

Post-doctoral work in

Other degree in

3. Please check the boxes to identify where you received any training (classes, workshops, mentoring, professional development, readings, etc.) related to business communication practice, theory, pedagogy, or research methods.

\begin{tabular}{|c|c|c|c|c|c|}
\hline & Practice & Theory & Pedagogy & Research methods & N/A \\
\hline \multicolumn{6}{|l|}{ Bachelor's } \\
\hline \multicolumn{6}{|l|}{ Master's } \\
\hline \multicolumn{6}{|l|}{ Doctorate } \\
\hline \multicolumn{6}{|l|}{ Post-doctoral } \\
\hline Other & & & & & \\
\hline
\end{tabular}

4. If you marked "other" in any category above, please indicate what type of organization provided the education type you selected. If multiple organizations provided the education you marked in other, please identify what types of organization provided what type of education (such as "Corporate Training - Practice" or "Non-degree program - Research Methods").

5. Does your current institution offer a graduate program where students can study and research business communication? If yes, what is the name of that program?

(This does not have to be a strictly business communication program--it can be any program where business communication can be studied, such as rhetoric \& composition, professional communication, technical communication, or other program.)

6. Please list the name and institution of 2-3 other graduate programs you know of where business communication can be studied at a graduate level.

(This does not have to be a strictly business communication program--it can be any program where business communication can be studied, such as rhetoric \& composition, professional communication, technical communication, or other program.) 